\title{
The Small Water Cycle in the Czech Landscape: How Has It Been Affected by Land Management Changes Over Time?
}

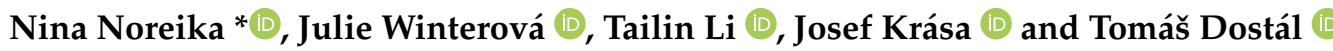 \\ Faculty of Civil Engineering, Czech Technical University in Prague, 16000 Prague, Czech Republic; \\ julie.winterova@fsv.cvut.cz (J.W.); tailin.li@fsv.cvut.cz (T.L.); josef.krasa@fsv.cvut.cz (J.K.); \\ dostal@fsv.cvut.cz (T.D.) \\ * Correspondence: nina.noreika@fsv.cvut.cz
}

Citation: Noreika, N.; Winterová, J.; Li, T.; Krása, J.; Dostál, T. The Small Water Cycle in the Czech Landscape: How Has It Been Affected by Land Management Changes Over Time? Sustainability 2021, 13, 13757. https:// doi.org/10.3390/su132413757

Academic Editors: Uta Schirpke and Erich Tasser

Received: 19 November 2021 Accepted: 10 December 2021 Published: 13 December 2021

Publisher's Note: MDPI stays neutral with regard to jurisdictional claims in published maps and institutional affiliations.

Copyright: (c) 2021 by the authors. Licensee MDPI, Basel, Switzerland. This article is an open access article distributed under the terms and conditions of the Creative Commons Attribution (CC BY) license (https:// creativecommons.org/licenses/by/ $4.0 /)$.

\begin{abstract}
For the Czech Republic to recover from the effects of past mismanagement, it is necessary to determine how its landscape management can be improved holistically by reinforcing the small water cycle. We conducted a scenario analysis across four time periods using SWAT (Soil and Water Assessment Tool) to determine the effects of land use, land management, and crop rotation shifts since the 1800s in what is now the Czech Republic. The 1852 and 1954 land-use scenarios behaved the most similarly hydrologically across all four scenarios, likely due to minimal landscape transformation and the fact that these two scenarios occur prior to the widespread incorporation of subsurface tile drainages across the landscape. Additionally, the crop rotation of 1920-1938 reinforces the small water cycle the most, while that of 1950-1989 reinforces the small water cycle the least. Diversified crop rotations should be incentivized to farmers, and increasing the areas of forest, brush, and permanent grassland should be prioritized to further reinforce the small water cycle. It is necessary to foster relationships and open communication between watershed managers, landowners, and scientists to improve the small water cycle and to pave the way for successful future hydrological modeling in the Czech Republic.
\end{abstract}

Keywords: landscape management; small water cycle; crop rotation; land-use change; scenario analysis; SWAT

\section{Introduction}

Since the modern era, the Czech Republic has always been intensively cultivated, and the culture places a high value on Czech produce, livestock, and of course, beer. The Czech Republic is largely self-sufficient in its production of fruit, beef, pork, poultry, and eggs, and is a major exporter of hops and biofuel crops such as rapeseed [1]. While the local mindedness of the Czech people has remained unphased over the years, changes in political management have greatly affected how the Czech landscape retains water and reinforces the small water cycle. The small water cycle is a closed system in which water evaporated from a terrestrial area falls as precipitation in the same terrestrial area $[2,3]$. To reinforce the small water cycle, great emphasis is placed on increasing the retention capacity of a landscape while reducing the potential for surface runoff $[4,5]$.

In the area that is now the Czech Republic, agricultural intensification started during the Communist regime, wherein large, monotonous agricultural fields (Appendix A, Figure A1), subsurface tile drainage systems, and artificially straightened streams were incorporated across the landscape [6,7].

The large, monotonous cultivated fields that are still present across the Czech Republic can contribute to significant runoff events and increased soil erosion, which in turn increases reservoir siltation rates [8]; the average field size in the Czech Republic is $>10$ ha [9]. The subsurface tile drainage systems that are still widely present across the Czech landscape cover an area $>1.1$ million ha [10]. although many are no longer properly maintained, these systems drain agricultural soils faster than they would naturally, and divert infiltrated water 
directly into the stream network, disallowing proper deep percolation and groundwater recharge. Additionally, many streams and rivers throughout the Czech Republic have been concrete-lined and artificially straightened [6], which can lead to several problems in the landscape. The first is the reduction of alluvial processes, which decreases infiltration and groundwater recharge [6]. Secondly, straightening a stream/river can reduce the riffle-pool sequencing, in turn reducing the aquatic biodiversity that would otherwise be present in a natural lotic water body. The straightening and smoothing of a lotic system can also contribute to more sediment leaving the system as resistance is reduced and the slope increased (by straightening), and in-stream resuspension is more likely (by smoothing), which leads to greater reservoir siltation.

Since governmental shifts in the Czech Republic in 1989, there have been some significant land-use changes, especially with the distribution of arable land versus forested land [6]. Between 1989 and 2000, many areas of previously arable (with low productivity) land were shifted to forests and grasslands while arable lands were relocated to more fertile soils [6,11]. However, since 2000, there have been minimal shifts in land-use; there has been a slight decrease in the percent cover of arable land which has been replaced by an impervious cover, such as expanding industry, developments, and roadways [6]. In addition to land-use changes, there have also been significant crop changes over the last century. The Czech Republic has shifted from primarily growing potatoes, oats, and rye to higher-profit crops driven by the free market and government subsidies, such as winter wheat, rapeseed, and maize [12]. While there have been some improvements in Czech landscape management with smaller farms incorporating IPA (integrated pest management for agriculture) guidelines and agricultural conservation practices [1], much of the Czech Republic's cropland cover is managed by large-scale agricultural conglomerates, with profit being the top priority.

Hydrologic models are a relatively easy and non-invasive way to monitor the water balance of a landscape and can aid basin managers as decision-making tools. The Soil and Water Assessment Tool (SWAT) is one of the most widely used hydrologic models in modern literature [13-16]. SWAT divides a basin into sub-basins based on the delineated stream network and then further divides the sub-basins into HRUs (hydrologic response units), which are noncontinuous areas that have identical user-defined soil, slope, and landuse properties. Each HRU is treated as its own individual unit throughout the modeling process. SWAT has been used effectively anywhere from the farm to the continental scale and has been previously applied to the Czech landscape [17-21].

This study investigates the following questions: (i) How do the land-use changes since the 1800s affect the small water cycle in a Czech agricultural landscape?; (ii) Do crop changes have similar impacts on the small water cycle as the land-use and management changes throughout the political eras of the modern Czech Republic?; (iii) Have the management and land-use changes since 1989 improved the Czech landscape by reinforcing the small water cycle?

\section{Materials and Methods}

\subsection{Study Watershed}

The Vrchlice basin ("Vrchlice") outlet is located $65 \mathrm{~km}$ from Prague and is approximately $97 \mathrm{~km}^{2}$ (Figure 1). Vrchlice is primarily cropland (54\% by area, Figure 2) but also includes large forested areas and smaller townships as well as a network of reservoirs (137 in total) that provide cultural, municipal, and hydrological value to the landscape [8]. The basin drains into the Vrchlice reservoir, which provides drinking water to the surrounding areas, including the town of Kutná Hora. Vrchlice is primarily a lowland area with altitudes ranging from 308 to $555 \mathrm{~m}$ a.s.l., and its outlet is located at $49^{\circ} 55^{\prime} 37.211^{\prime \prime} \mathrm{N}, 15^{\circ} 13^{\prime} 37.07^{\prime \prime} \mathrm{E}$. 
(a)

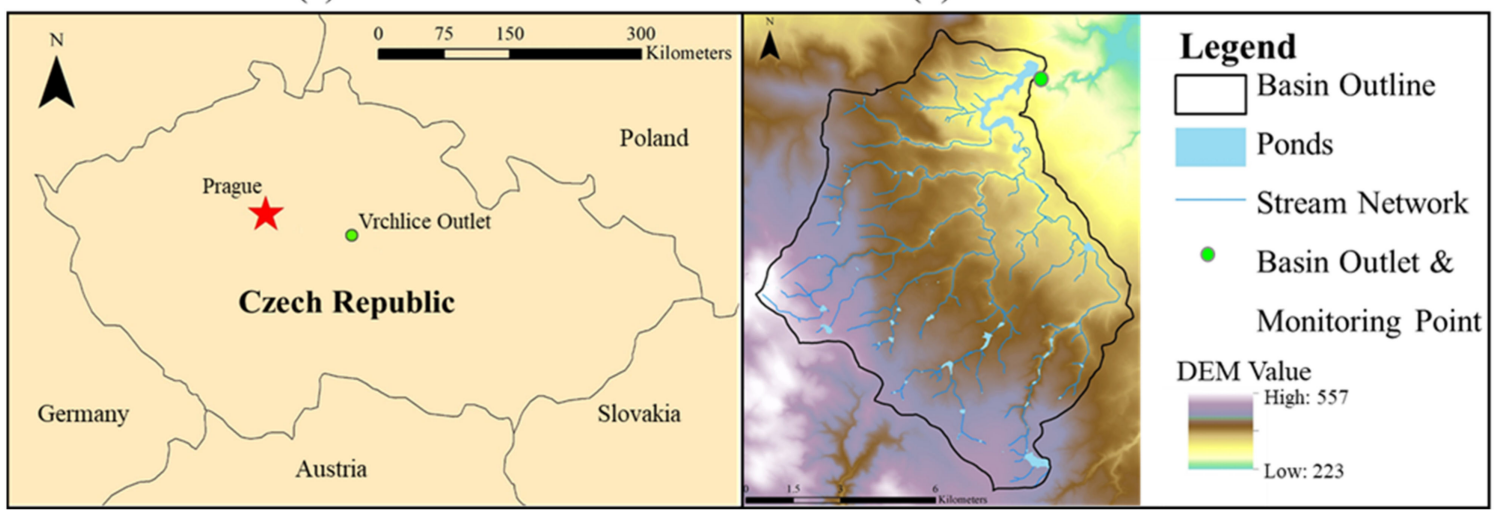

Figure 1. (a) Map of the Czech Republic with Prague and the outlet of Vrchlice (the study watershed) highlighted for reference; (b) $5 \mathrm{~m}$ resolution DEM of Vrchlice and its immediate surroundings.
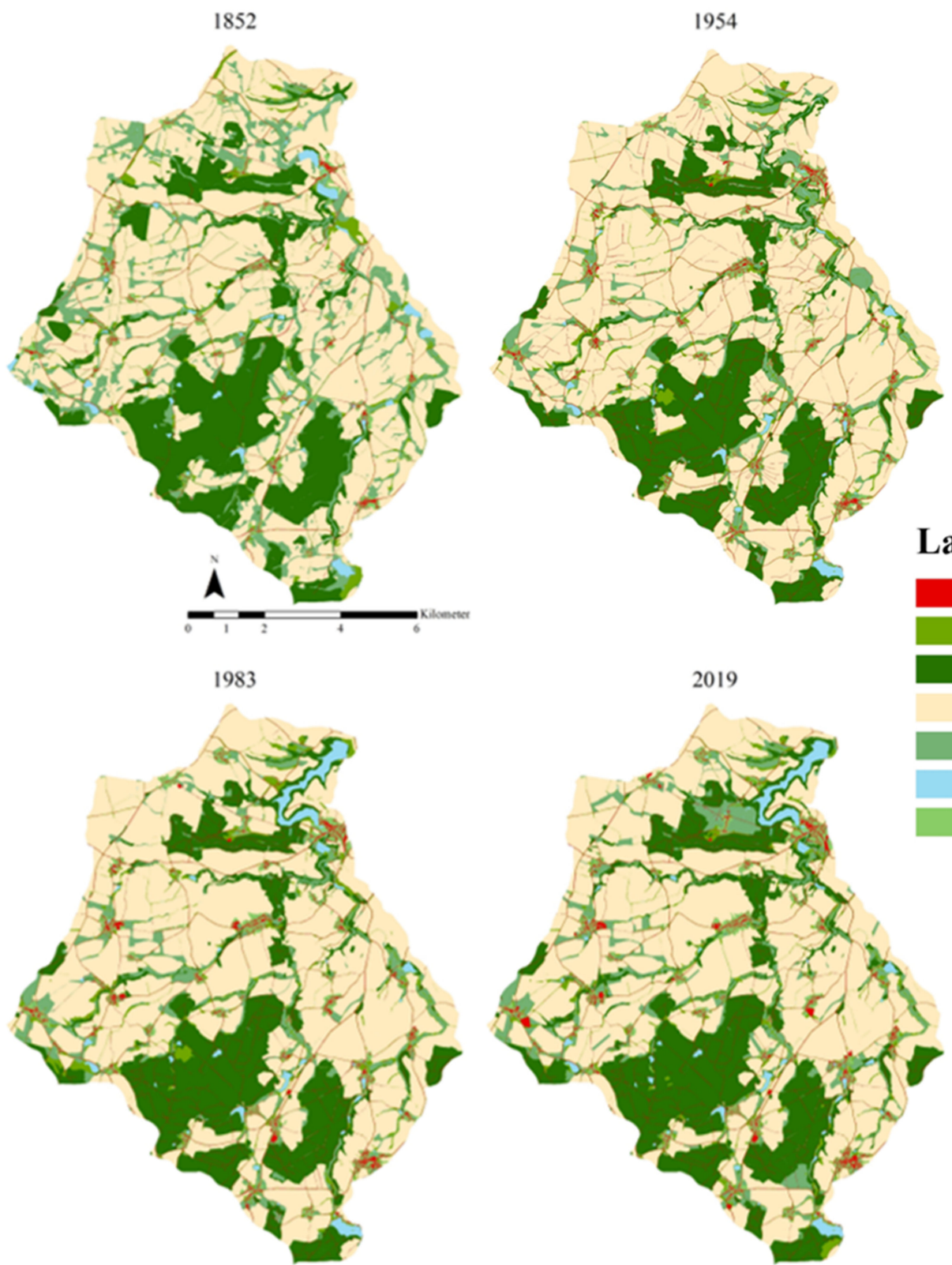

Land Use

Impervious

Brush

Forest

Cropland

Grassland

Water

Gardens

Figure 2. Land-use changes across the Vrchlice basin over time. 
The catchment is covered mostly by clayey soils classified as Cambisols [8]. There is minimal groundwater interaction with the surface due to metamorphic bedrock. The few springs that are present are quite dependent on the weather; they flow if there is rain but are dry if there is not. The streams in the Vrchlice basin are quite flashy and reactive to rainfall and can run dry during periods of prolonged drought. The discharge at the basin's outlet (from the Vrchlice Reservoir) has been measured at the daily timestep since January of 1979 by the Elbe River Basin Authority. The climate of this region is characterized as humid continental. The rainy season spans from May through August, and the highest precipitation rate is typically in July $(76 \mathrm{~mm} / \mathrm{month})$, while the lowest precipitation rate is in February ( $23 \mathrm{~mm} / \mathrm{month})$.

Vrchlice has a much higher cropland area cover (+15\%) than the Czech Republic on average. In Vrchlice, there have been fluctuations in cropland cover over time, reflected by the rise and subsequent fall of communism and its associated policies. The largest percent area change across the basin is seen in the reduction of permanent grasslands (Table 1). Otherwise, there are some land-use changes that are consistent with the Czech average (as previously described); many of the land-use changes are not reflected in total percentages but are the result of shifts in the spatial distribution of various land-use classes (Figure 2).

Table 1. Land-use cover changes (in percent area cover) across the Vrchlice basin over time.

\begin{tabular}{ccccc}
\hline Land Use & $\mathbf{1 8 5 2}$ & $\mathbf{1 9 5 4}$ & $\mathbf{1 9 8 3}$ & $\mathbf{2 0 1 9}$ \\
\hline Impervious & 2 & 3 & 3 & 3 \\
Brush & 3 & 3 & 4 & 4 \\
Forest & 23 & 23 & 23 & 25 \\
Cropland & 56 & 60 & 58 & 54 \\
Grassland & 13 & 7 & 6 & 8 \\
Water & 1 & 1 & 2 & 2 \\
Gardens & 2 & 3 & 4 & 4 \\
\hline
\end{tabular}

\subsection{SWAT Model Description}

The SWAT model for Vrchlice was run at a monthly timestep from 2001 through 2019 with a 5-year warmup period from 1996-2000. Although daily discharge data was available for calibration, a monthly timestep was selected for two reasons: (i) to minimize extreme daily fluctuations in discharge due to extreme precipitation events or reservoir management and (ii) to make the computational time more efficient. The boundaries of the Vrchlice basin, its contained sub-basins, and the stream network were largely DEM-based, but a stream shapefile was available for ground-truthing. Some sub-basins were combined to better reflect the hydrologic conditions in the basin, e.g., several sub-basins near the outlet needed to be combined to reflect one continuous sub-basin to encompass the Vrchlice Reservoir. A total of 63 sub-basins were delineated across the Vrchlice basin. Individual HRUs were defined by each unique land-use type, 3 slope classes $(0-2 \%, 2-8 \%$, and $8+\%$, typical for an agricultural landscape), and soils that covered at least $10 \%$ of the basin; this classification scheme resulted in 1058 HRUs with an average HRU size of approximately 9 ha.

\subsection{Input Data}

The soil map used to develop this model was compiled from various sources, including unpublished data from the Czech Research Institute of Soil Conservation (which has been conducting an intensive soil sampling effort across the basin) and the State Land Office of the Czech Republic (Table 2). The DEM was obtained from the fourth generation of the digital relief model of the Czech Republic (DMR4G). The model point cloud was processed to obtain a $5 \mathrm{~m}$ spatial resolution. The land-use maps were obtained from ZABAGED (Fundamental Base of Geographic Data of the Czech Republic; provided by the State Administration of Surveying and Cadaster (ČUZK)) that were corrected by LPIS (Land Parcel Identification System; provided by the Czech Ministry of Agriculture) 
agricultural land surveys which were manually edited over historical orthophotos of the Czech Republic [22].

Table 2. Input data and sources used for SWAT modeling.

\begin{tabular}{|c|c|c|c|}
\hline & Input Data & Description & Source \\
\hline \multirow[t]{2}{*}{ Meteorological Data } & $\begin{array}{c}\text { Extreme } \\
\text { Temperatures }\end{array}$ & $\begin{array}{l}\text { Minimum and } \\
\text { maximum daily } \\
\text { temperatures } \\
(1996-2019)\end{array}$ & $\begin{array}{c}\text { Czech } \\
\text { Hydrometeorological } \\
\text { Institute }\end{array}$ \\
\hline & Precipitation & $\begin{array}{l}\text { Total daily } \\
\text { precipitation } \\
(1996-2019)\end{array}$ & $\begin{array}{c}\text { Czech } \\
\text { Hydrometeorological } \\
\text { Institute }\end{array}$ \\
\hline \multirow{3}{*}{ Spatial Data } & DEM & $\begin{array}{l}\text { Digital elevation } \\
\text { model } \\
\text { (5 m resolution) }\end{array}$ & $\begin{array}{l}\text { LiDAR Survey: Czech } \\
\text { Institute of Geodesy } \\
\text { and Cartography }\end{array}$ \\
\hline & Soils & 1:5000 soil map & $\begin{array}{l}\text { Czech Research } \\
\text { Institute of Soil } \\
\text { Conservation \& the } \\
\text { State Land Office of } \\
\text { the Czech Republic }\end{array}$ \\
\hline & Land Use & 1:10,000 land use map & ZABAGED \& LPIS \\
\hline
\end{tabular}

The typical crop cover percentages were provided by the Czech Statistical Office (Table 3). The current (2019) crop percentages were used for the land-use change scenarios. This was done for two reasons: (i) because the calibrated and validated model is based on this crop configuration and (ii) to isolate the effects of land-use change. Varying crop rotations were incorporated into SWAT as management schedules to reflect their relative percent cover and were utilized in a sub-basin scenario analysis.

Table 3. Typical crop cover percentages in the Czech Republic, limited to the top 5 most prevalent crops for modeling purposes [21].

\begin{tabular}{cccc}
\hline Crop & $\mathbf{1 9 2 0 - 1 9 3 8}$ & $\mathbf{1 9 5 0 - 1 9 8 9}$ & $\mathbf{2 0 1 9}$ \\
\hline Potatoes & $\mathbf{2 0 \%}$ & $10 \%$ & - \\
Oats & $25 \%$ & $15 \%$ & - \\
Spring Barley & $15 \%$ & $30 \%$ & $16 \%$ \\
Rye & $25 \%$ & $10 \%$ & - \\
Winter Wheat & $15 \%$ & $35 \%$ & $40 \%$ \\
Rapeseed & - & - & $\mathbf{2 0 \%}$ \\
Corn & - & - & $\mathbf{2 0 \%}$ \\
Winter Barley & - & - & $4 \%$ \\
\hline
\end{tabular}

\subsection{Vrchlice Ponds and Reservoirs}

Parameters for most of the reservoirs and ponds found across Vrchlice were extracted from 1991 and 1992 maps published by the Czech Republic's Ministry of the Environment. The reservoirs, without parameters available, in the aforementioned maps were located in aerial photographs (mapy.cz) to determine whether they were still present and connected to the stream network. A field campaign was executed during which 23 "undocumented" reservoirs were surveyed, and relevant inputs for SWAT were estimated. Ultimately, 14 reservoirs and 23 ponds were determined to be hydrologically significant (i.e., of substantial size and connected to the stream network) and incorporated into SWAT (according to SWAT, a reservoir is located at the outlet of a sub-basin while a pond is located anywhere else in the sub-basin). There is no central database of reservoir management in the Vrchlice basin, so in SWAT, the reservoir outflow was "simulated controlled outflow-target release," and 
the monthly target reservoir storage was set equal to the reservoir volume at its principal spillway. The target days needed for a pond to reach its target storage was set to zero, as most of the small pond and reservoir water levels in the Czech Republic are maintained at the principal spillway.

\subsection{SWAT Sensitivity Analysis, Calibration, Validation, and Performance Evaluation}

The sensitivity analysis, calibration, and validation for the SWAT model of Vrchlice were all conducted via the SUFI2 method using SWAT-CUP 2019 v5.4.1. The most sensitive parameters according to the model response were determined through a global sensitivity analysis. Prior to calibration and validation, extreme outlying discharge months were removed; these are likely due to individual reservoir management that is not regulated by any governing body, nor are the reservoir activities recorded in any public database. The calibration of the model was run from 2001 through 2012 at the monthly timestep. Many iterations of over 2000 simulations were run across 21 variables until satisfactory statistical criteria were met (Table 4); the model performance indicators include the Nash-Sutcliff efficiency (NSE), percent bias (PBIAS), coefficient of determination $\left(\mathrm{R}^{2}\right)$, and the KlingGupta Efficiency (KGE). The validation of the model was run from 2013 through 2016 at the monthly timestep.

Table 4. Parameters used for model calibration in SWAT-CUP. (V: replace, A: absolute, R: relative; ${ }^{*} p<0.05,{ }^{\dagger}$ only applied to land use AGRC).

\begin{tabular}{|c|c|c|c|c|c|}
\hline Parameter & Description & Method & File & Min & Max \\
\hline SURLAG & Surface runoff lag coefficient (days) & $\mathrm{V}$ & BSN & 1 & 12 \\
\hline SMTMP * & Snow melt base temperature $\left({ }^{\circ} \mathrm{C}\right)$ & $\mathrm{V}$ & BSN & -5 & 5 \\
\hline SFTMP * & Snowfall temperature $\left({ }^{\circ} \mathrm{C}\right)$ & $\mathrm{V}$ & BSN & -5 & 5 \\
\hline ESCO & Soil evaporation compensation factor & $\mathrm{V}$ & BSN & 0.5 & 0.98 \\
\hline GW_DELAY & Delay time for aquifer recharge (days) & $\mathrm{V}$ & GW & 0 & 500 \\
\hline GWQMN * & $\begin{array}{l}\text { Threshold water level in shallow aquifer for base flow } \\
\qquad(\mathrm{mm})\end{array}$ & $\mathrm{V}$ & GW & 0 & 5000 \\
\hline ALPHA_BF & Baseflow alpha factor $\left(\right.$ days $\left.^{-1}\right)$ & $\mathrm{V}$ & GW & 0.001 & 1 \\
\hline GW_REVAP * & Groundwater revap coefficient & $\mathrm{V}$ & GW & 0.02 & 0.2 \\
\hline RCËRG_DP & Deep aquifer percolation fraction & $\mathrm{V}$ & GW & 0.001 & 1 \\
\hline REVAPMN * & $\begin{array}{l}\text { Threshold water depth in the shallow aquifer for } \\
\text { "revap" or percolation to the deep aquifer (mm) }\end{array}$ & $\mathrm{V}$ & GW & 0 & 500 \\
\hline CANMX & Maximum canopy water storage $(\mathrm{mm})$ & $\mathrm{R}$ & HRU & -0.2 & 0.2 \\
\hline OV_N & Manning's $\mathrm{n}$ value for overland flow & $\mathrm{V}$ & HRU & 0.05 & 0.8 \\
\hline DEP_IMP *† & Depth to impervious layer in soil profile (mm) & $\mathrm{A}$ & HRU & -1000 & 1000 \\
\hline GDRAIN_BSN $^{\dagger}$ & Drain tile lag time (hours) & A & MGT & -40 & 40 \\
\hline TDRAIN_BSN * ${ }^{+}$ & Time to drain soil to field capacity (hours) & A & MGT & -40 & 40 \\
\hline DDRAIN_BSN $^{+}$ & Depth to subsurface drain (mm) & A & MGT & -500 & 500 \\
\hline $\mathrm{CN} 2 *$ & Initial SCS curve number for moisture condition II & $\mathrm{R}$ & MGT & -0.1 & 0.1 \\
\hline $\mathrm{CH} \_\mathrm{K} 2$ & Effective hydraulic conductivity of channel $\left(\mathrm{mm} \mathrm{h}^{-1}\right)$ & $\mathrm{V}$ & RTE & 0.025 & 150 \\
\hline CH_N2 & Manning's $\mathrm{n}$ for main channel & $\mathrm{V}$ & RTE & 0.02 & 0.14 \\
\hline SOL_AWC & Available water capacity $(\mathrm{mm})$ & $\mathrm{R}$ & SOL & -0.2 & 0.2 \\
\hline SOL_K K* & Saturated hydraulic conductivity $\left(\mathrm{mm} \mathrm{h}^{-1}\right)$ & $\mathrm{R}$ & SOL & -0.2 & 0.2 \\
\hline
\end{tabular}

\subsection{Land-Use Changes: Basin Scale Scenario Analysis}

Three land-use scenarios were run in addition to the calibrated model (Table 1). The scenarios are defined by land-use changes across time: 1852 (pre-Communist Era), 1954 (early Communist Era), 1983 (late-Communist Era), and 2019 (default/calibrated model and post-Communist Era; Figure 2). In the pre-Communist Era scenario, there were typically buffer zones of forest or brush between agricultural fields. In the Communist and post-Communist eras, the fields were much larger and more monotonous, which increased the probability of surface runoff events and erosion; during these time periods, subsurface 
tile drainage systems were incorporated across all agricultural land-uses in the Vrchlice SWAT model.

\subsection{Landscape Management Changes: Sub-Basin Scale Scenario Analysis}

To determine the effects of crop changes across the political eras in the Czech Republic, four primarily agricultural sub-basins were selected and isolated (at least 150 hectares with $>80 \%$ agricultural land-use cover) from Vrchlice; their water balance properties were compared across three crop-change scenarios (Table 3) that included the major crops from 1920-1938 (pre-Communist era), 1950-1989 (Communist era), and the current conditions (post-Communist era) (Table 3; Figure 3) [23].

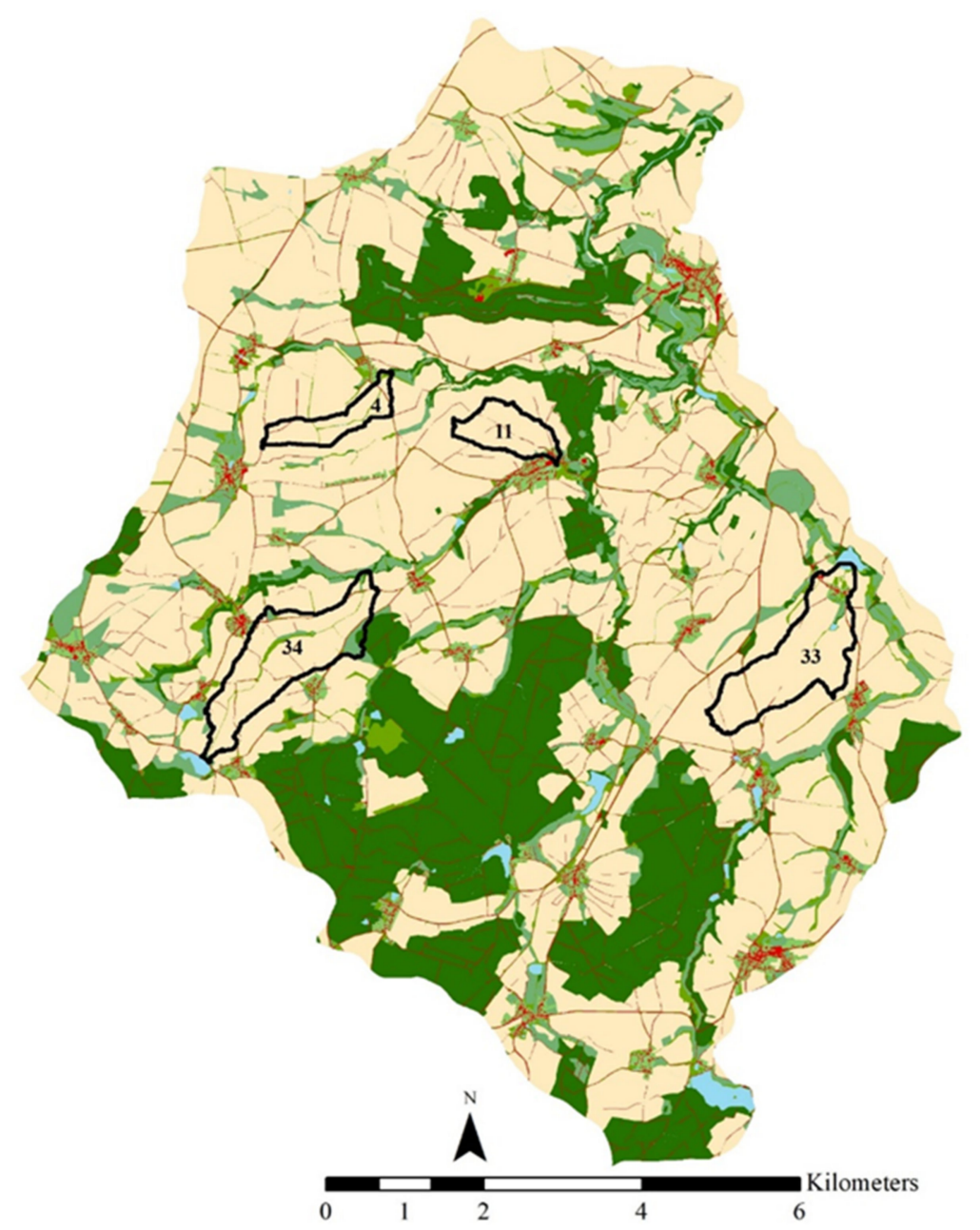

Figure 3. The four primarily agricultural sub-basins identified for crop-change impact analysis, identified by their SWAT sub-basin ID number; the land-use map is 1954.

\section{Results}

\subsection{SWAT Model Sensitivity Analysis}

Nine of the 21 variables assessed in calibration significantly affected the discharge output of the SWAT model for Vrchlice (Table 5). Two of the nine parameters are snowfall (SFTMP) and snowmelt (SMTMP) temperatures, which determine when snowfall accumulates and subsequently melts, which delays discharge reaction time to precipitation events. Three of the nine parameters govern groundwater processes. GWQMN is the threshold depth of water in the shallow aquifer that is required for a return flow to occur. GW_REVAP is the groundwater "revap" coefficient. As this value approaches 0 , water movement from the shallow aquifer to the root zone is restricted, whereas as it approaches 1, the rate of transfer from the shallow aquifer approaches the rate of potential evapotranspiration. 
REVAPMN is the minimum depth of water necessary in the shallow aquifer for percolation to the deep aquifer to occur; this variable controls the movement of water from the shallow aquifer to the unsaturated zone. Two parameters are associated with the incorporation of generalized tile drainages across the agricultural land-use classes in Vrchlice. The parameter that defines a layer of soil with lower hydraulic conductivity than those above it is DEP_IMP, and TDRAIN_BSN is the time the drainage system takes to drain the soil to field capacity. The SCS curve number (CN2) is a function of a soil's permeability, land-use, and antecedent soil water conditions. On average, the $\mathrm{CN} 2$ was $8 \%$ lower than the default value for each land use, indicating a higher modeled infiltration than expected. Finally, the last variable that significantly affected the modeled discharge at Vrchlice's outlet is the saturated hydraulic conductivity of the soil, which was modeled to be $19 \%$ lower than the input values. This discrepancy may be due to significant generalizations made when aggregating soil data from different governmental and academic sources.

Table 5. Sensitive parameters and their calibrated (adjusted) values.

\begin{tabular}{ccccc}
\hline \multirow{2}{*}{ Parameter } & Method & \multicolumn{3}{c}{ Calibration Values } \\
\cline { 3 - 5 } & & Minimum & Adjusted & Maximum \\
\hline SMTMP & Replace & 5 & $2.1^{\circ} \mathrm{C}$ & 5 \\
SFTMP & Replace & -5 & $-2.1^{\circ} \mathrm{C}$ & 5 \\
GWQMN & Replace & 0 & $513 \mathrm{~mm}$ & 5000 \\
GW_REVAP & Replace & 0.02 & 0.18 (coefficient) & 0.2 \\
REVAPMN & Replace & 0 & $488 \mathrm{~mm}$ & 500 \\
DEP_IMP & Absolute & -1000 & $-538 \mathrm{~mm}$ & +1000 \\
TDRAIN_BSN & Absolute & -48 & $-43 \mathrm{~h}$ & +48 \\
CN2 & Relative & $-10 \%$ & $-8 \%$ & $+10 \%$ \\
SOL_K & Relative & $-20 \%$ & $-19 \%$ & $+20 \%$ \\
\hline
\end{tabular}

\subsection{SWAT Model Calibration and Validation}

Successful model calibration and validation were obtained via a semi-automatic calibration method using SWAT-CUP 2019. The model performance indicators during the calibration period are considered to be "very good", while most indicators during the validation period are also considered to be "very good," and the PBIAS during validation is "good" (Table 6) [24].

Table 6. Model performance indicators for calibration and validation periods of the SWAT model for Vrchlice.

\begin{tabular}{ccc}
\hline $\begin{array}{c}\text { Model Performance } \\
\text { Indicator }\end{array}$ & $\begin{array}{c}\text { Calibration } \\
(\mathbf{2 0 0 1 - 2 0 1 2 )}\end{array}$ & $\begin{array}{c}\text { Validation } \\
\mathbf{( 2 0 1 3 - 2 0 1 6 )}\end{array}$ \\
\hline NSE & 0.84 & 0.72 \\
PBIAS & 3.1 & 8.1 \\
$\mathrm{R}^{2}$ & 0.85 & 0.72 \\
KGE & 0.86 & 0.81 \\
\hline
\end{tabular}

A scatterplot correlation is presented in Figure 4, with a trendline for reference. Paired $t$-tests comparing the measured versus modeled was conducted individually for the calibration and validation periods, and no significant differences were observed $(p>0.05)$. 

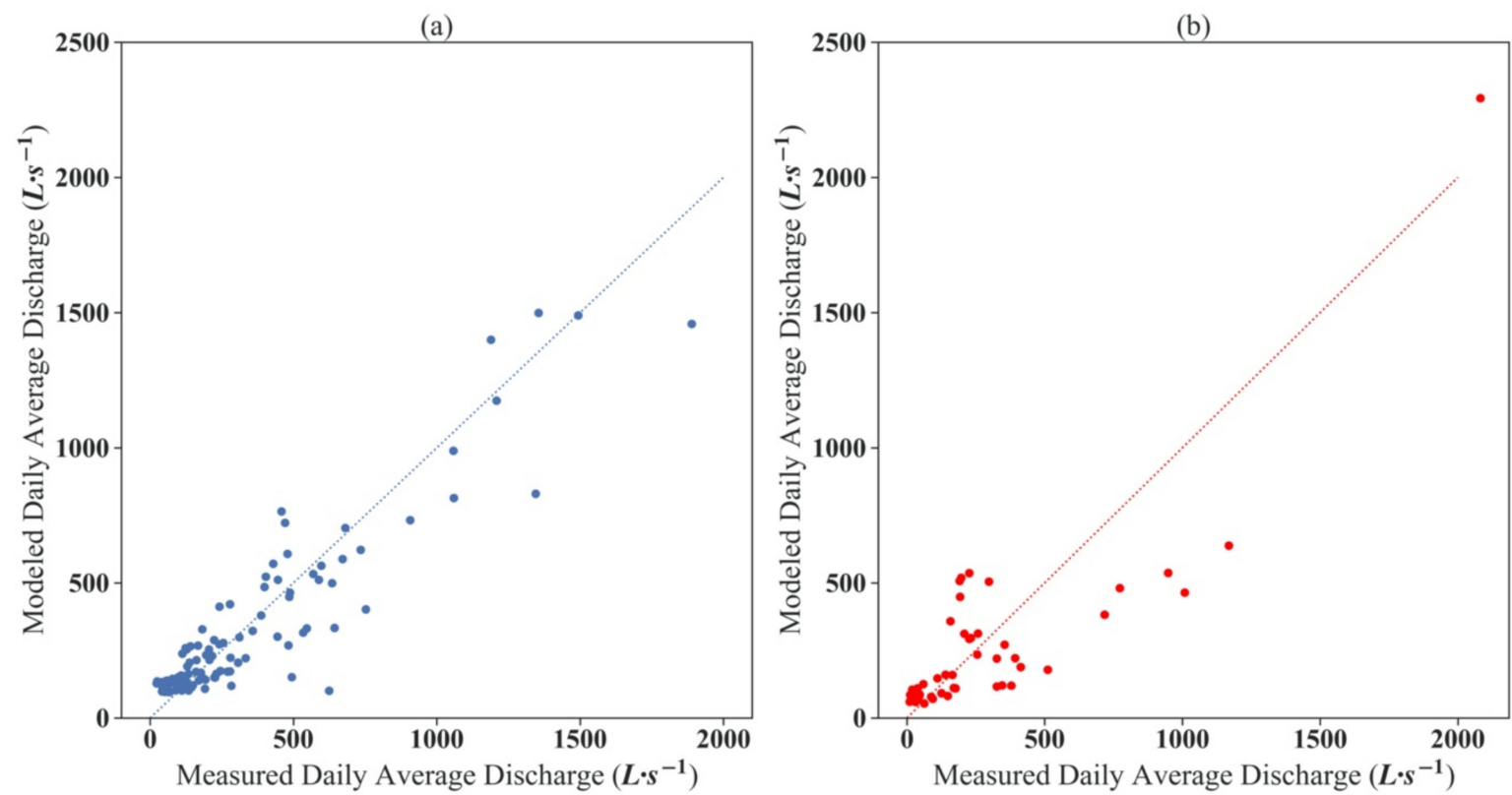

Figure 4. Measured daily average flows versus modeled daily average flows for (a) calibration period and (b) validation period at the monthly timescale.

\subsection{Land-Use Change Effects on the Small Water Cycle at the Basin Scale}

The following monthly basin-wide water balance parameters were analyzed across the four land-use change scenarios: evapotranspiration, the daily average discharge at the outlet, average soil water content, subsurface lateral flow contribution to streamflow, and percent of the precipitation that results in surface runoff. Evapotranspiration is not represented in a graphical form because the differences between the scenarios were very slight due to the fact that the total land-use changes in percent cover varied little across the four land-use change scenarios. Generally, the discharge at Vrchlice's outlet was highest in the 1852 scenario; the greatest extremes in streamflow were also observed in the 1852 scenario, while the most stable flows were recorded in the 2019 scenario (Figure 5). The 1852 and 1954 scenarios resulted in very similar water balance outputs except in discharge at the outlet, which is likely due to reservoir management. The soil water content across the basin was separated into two obvious groups, with much higher soil water contents in the 1852 and 1954 scenarios (pre-Communist and early Communist eras, respectively). The lower soil water contents in the 1983 and 2019 scenarios (late-Communist and post-Communist eras, respectively) are likely due to the incorporation of widespread tile drainage systems across the landscape in the 1970s (Figure 6), which also can explain the patterns observed in the percent rainfall resulting in surface runoff across the scenarios (Figure 7). Throughout most of the year, the highest subsurface lateral flow contribution to streamflow was modeled in the 1852 and 1954 land-use scenarios, while the 2019 land-use scenario exhibited the highest values from September through December (Figure 8). The lowest subsurface lateral flow contribution to streamflow values occurred in the 1983 land-use scenario across all months, and it also exhibited the greatest range in values across the year. 


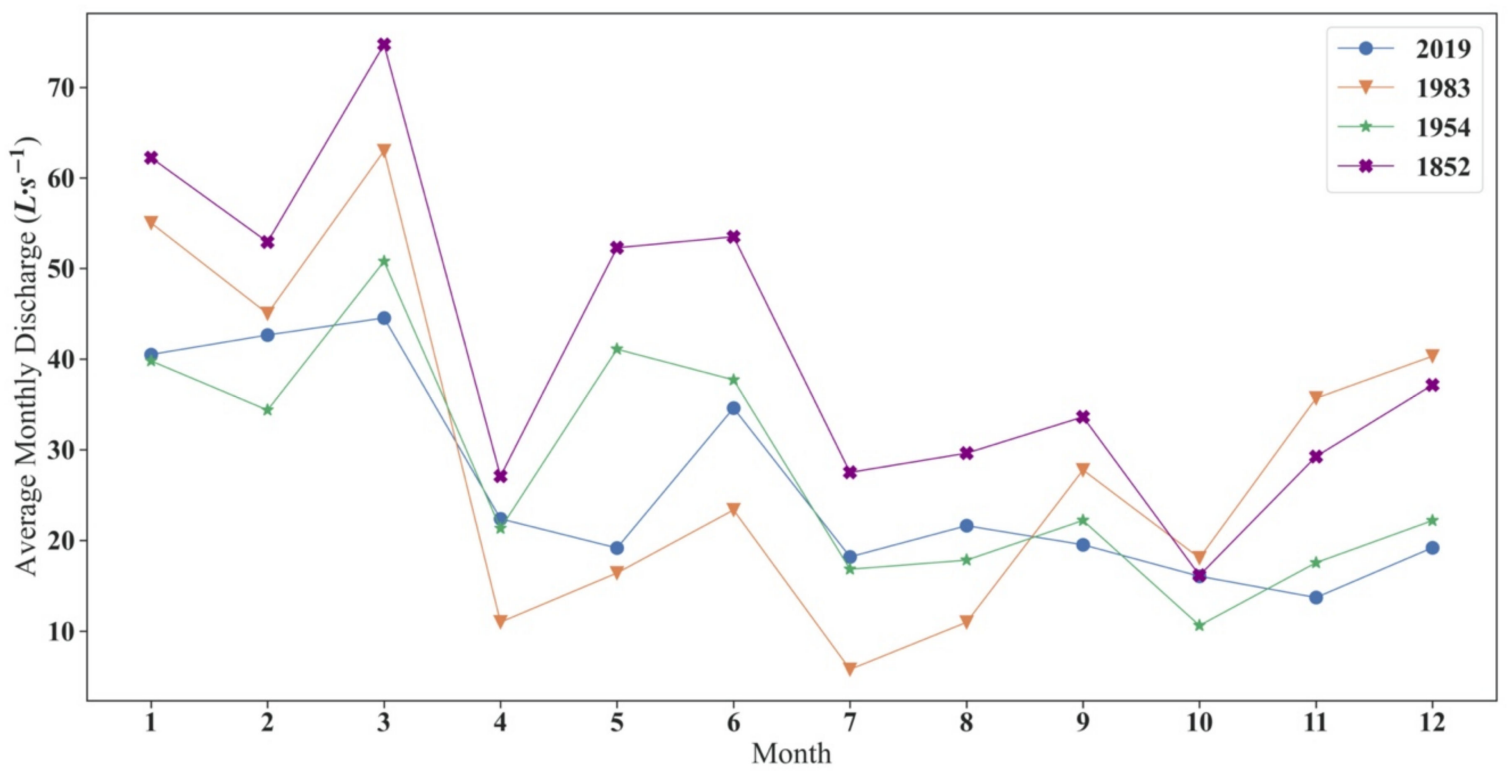

Figure 5. Daily discharge values averaged by month across land-use change scenarios.

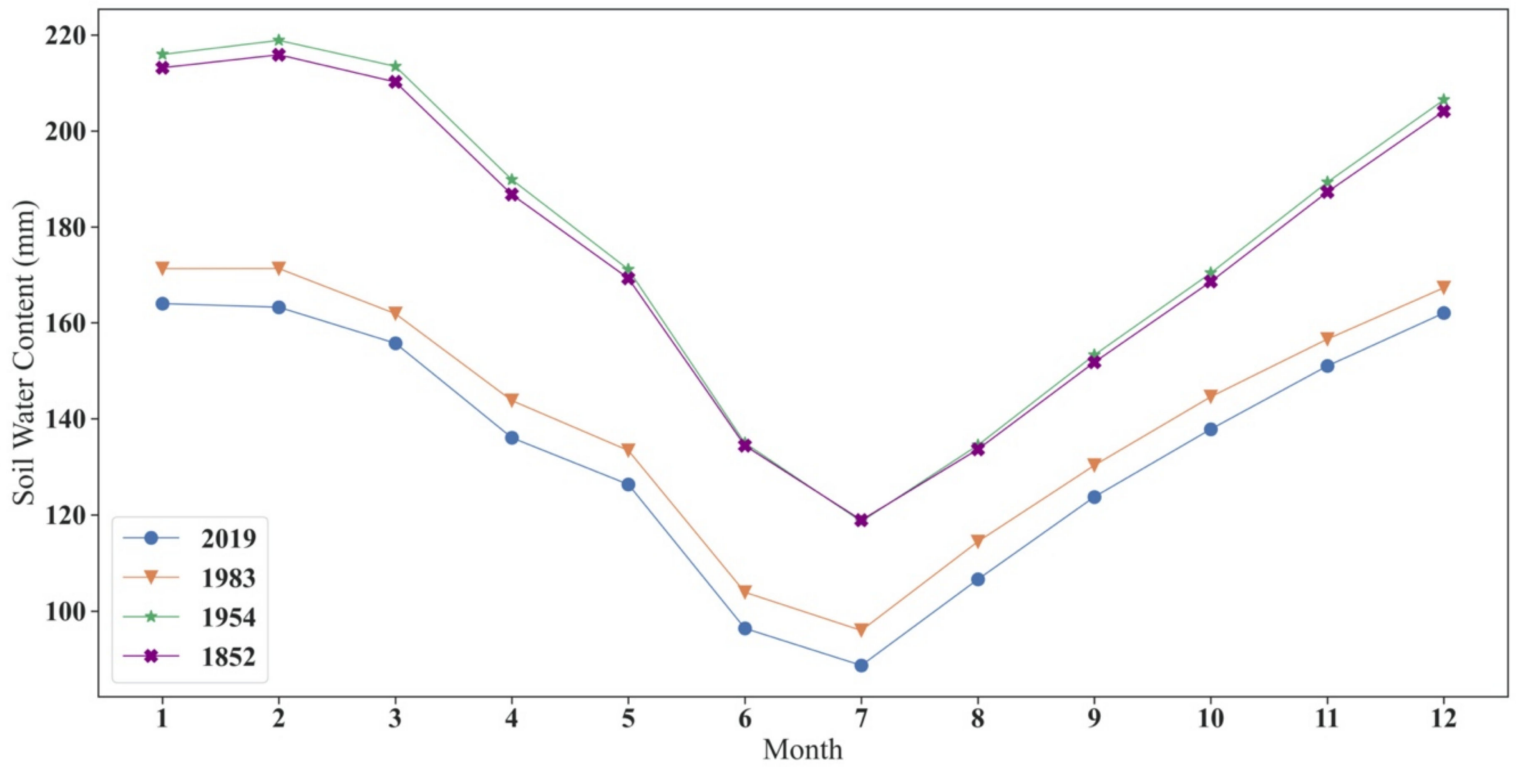

Figure 6. Monthly average soil water content across land-use change scenarios. 


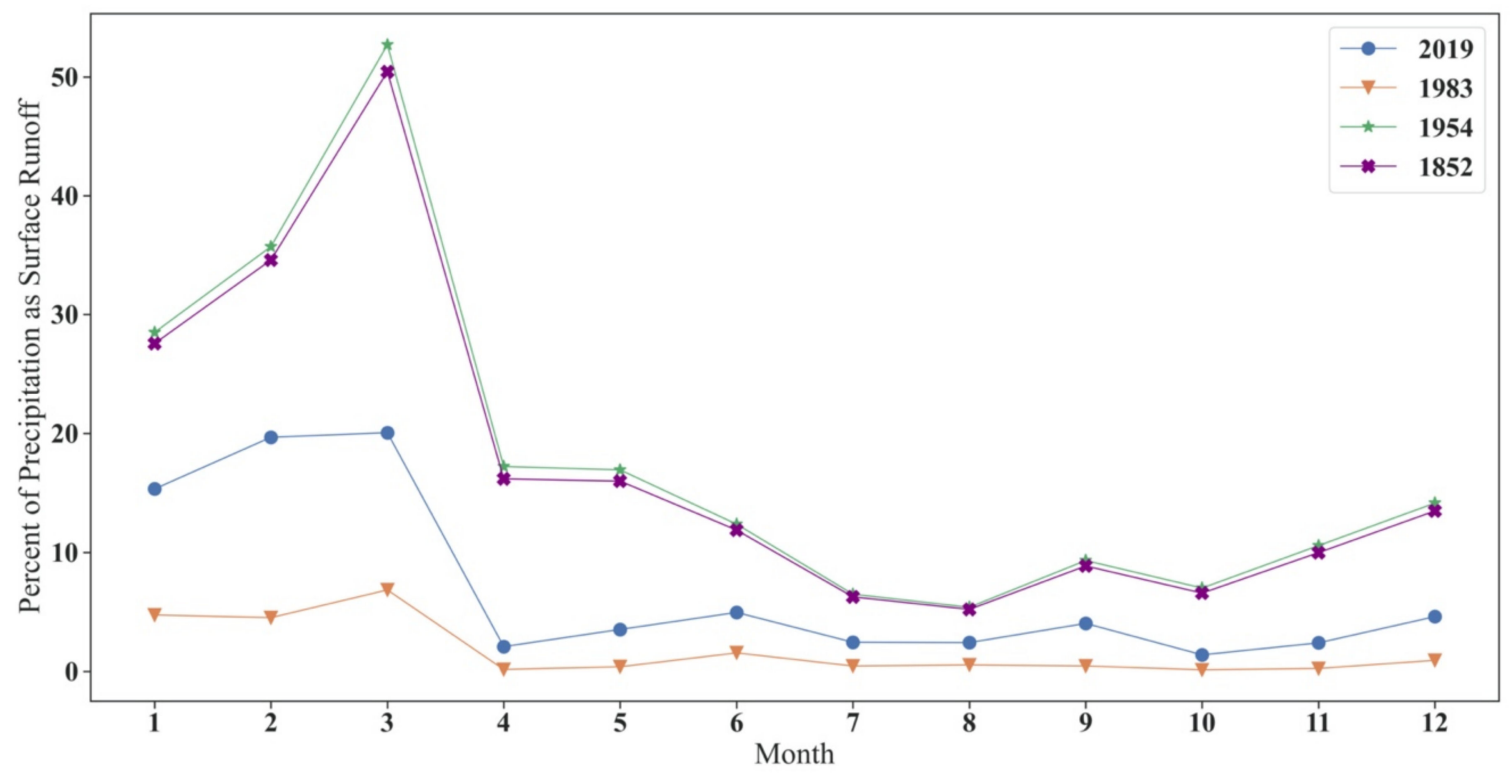

Figure 7. Percent of monthly precipitation resulting in surface runoff across land-use change scenarios.

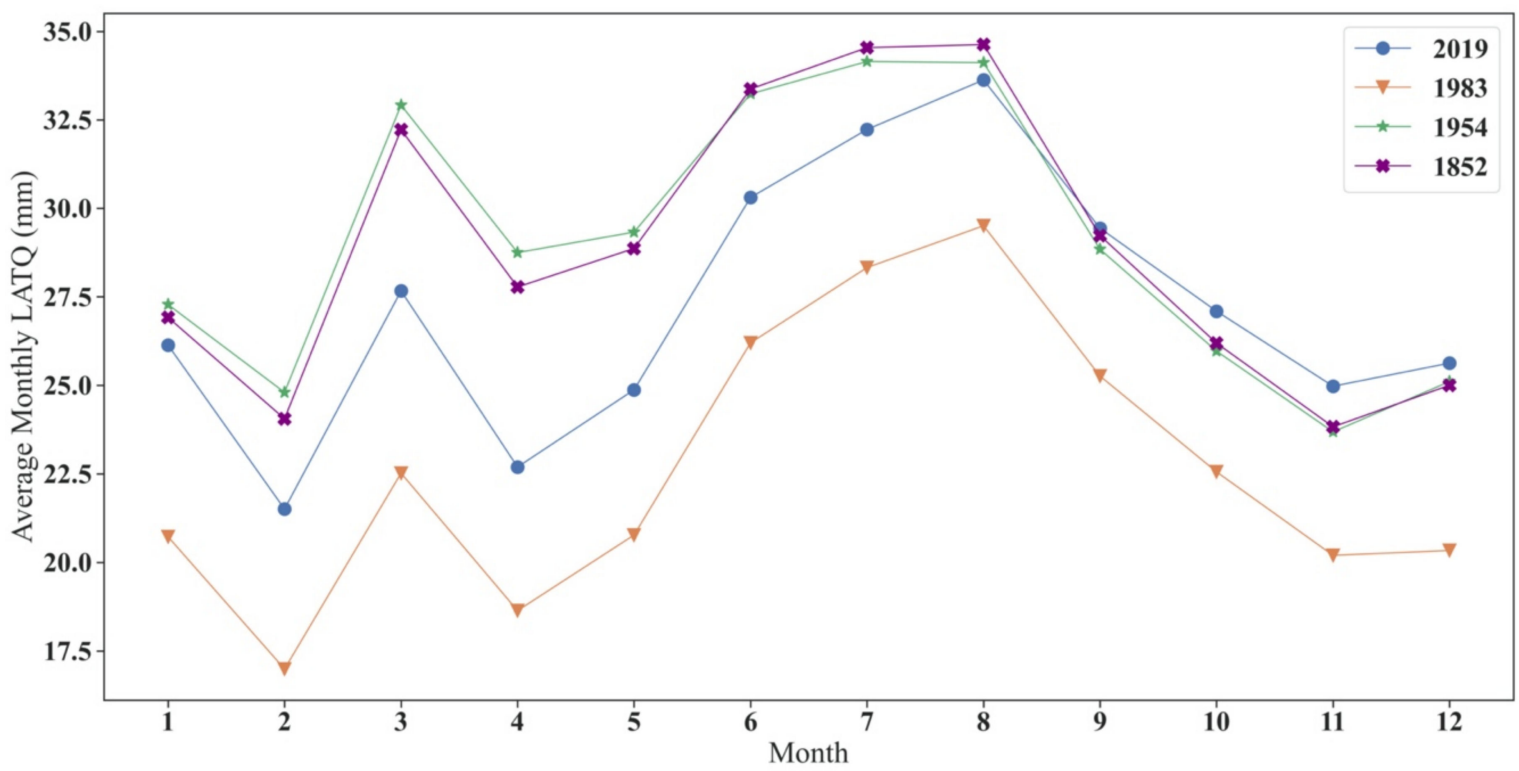

Figure 8. Average monthly subsurface lateral flow contribution to streamflow across land-use change scenarios.

\subsection{Crop Change Effects on the Small Water Cycle at the Sub-Basin Scale}

The following water balance variables were analyzed across the four agricultural sub-basins outlined in Figure 3: evapotranspiration (ET), average soil water content (SW), surface runoff (SURQ), subsurface lateral flow (LATQ), and discharge (Flow) at the subbasin's outlet. The results of this sub-basin scenario analysis are summarized in Table 7. The average values of each variable are color-coded to represent their reinforcement of the small water cycle i.e., a cell coded green indicates a higher reinforcement of the small water cycle compared to yellow, which is the intermediate value, and red is the crop configuration that contributes the least to the small water cycle. The standard deviations for each variable are also color-coded. The highest standard deviation for each variable indicates a higher hydrological variability within the respective crop rotation and, as such, is coded as red; the intermediate as yellow, and the lowest standard deviation is coded as green, which represents a more stable system and small water cycle. The pre-Communist era crop configuration tends to reinforce the small water cycle the most, followed by the 
post-Communist Era, with the Communist Era crop rotation having the most negative impact on the small water cycle.

Table 7. The effects of crop changes throughout political eras in the Czech Republic. This table compares the averages and standard deviations across water balance variables and is color-coded to represent their reinforcement of the small water cycle; green positively reinforces the small water cycle the most, followed by yellow, then red. ( $\mathrm{L}, \mathrm{M}, \mathrm{H}$ correspond to the lowest, middle, and highest values for each parameter across the three scenarios, respectively).

\begin{tabular}{ccccc}
\hline \multirow{2}{*}{ Parameter } & & $\begin{array}{c}\text { Pre-Communist } \\
\text { Era }\end{array}$ & Communist Era & $\begin{array}{c}\text { Post-Communist } \\
\text { Era }\end{array}$ \\
& & $\mathrm{M}$ & $\mathrm{L}$ & $\mathrm{H}$ \\
\multirow{2}{*}{ ET } & Average & $\mathrm{H}$ & $\mathrm{L}$ & $\mathrm{M}$ \\
& Stdev & $\mathrm{M}$ & $\mathrm{H}$ & $\mathrm{L}$ \\
\multirow{2}{*}{ SW } & Average & $\mathrm{L}$ & $\mathrm{M}$ & $\mathrm{H}$ \\
& Stdev & $\mathrm{L}$ & $\mathrm{H}$ & $\mathrm{M}$ \\
& Average & $\mathrm{L}$ & $\mathrm{M}$ & $\mathrm{H}$ \\
\hline \multirow{2}{*}{ SURQ } & Stdev & $\mathrm{M}$ & $\mathrm{H}$ & $\mathrm{L}$ \\
& Average & $\mathrm{M}$ & $\mathrm{H}$ & $\mathrm{L}$ \\
\hline \multirow{2}{*}{ LATQ } & Stdev & $\mathrm{M}$ & $\mathrm{H}$ & $\mathrm{L}$ \\
& Average & $\mathrm{L}$ & $\mathrm{H}$ & $\mathrm{M}$ \\
\hline \multirow{2}{*}{ Flow } & Stdev & & &
\end{tabular}

\section{Discussion}

\subsection{Hydrological Modeling with SWAT}

The biggest source of error in any model is the quality of the input data, which influences how a model will perform before it is even run $[25,26]$. Other sources of error include the model parameter, structural uncertainties, and output data uncertainties [26]. While SWAT may be the most used hydrologic model in modern studies, it is not immune to these sources of error [26]. Additionally, since SWAT is semi-physical based, it calculates many inputs and processes based on global or regional databases or from more generalized equations; some processes such as preferential flow or temporal changes in topsoil hydraulic properties, which are both significant in agricultural soils, cannot be modeled by SWAT [27-29]. All reservoir processes (filling, release, etc.) in Vrchlice were generalized because there is no central management or operations database for such activities in the Czech Republic. Most of the reservoirs across the Vrchlice basin are small fishponds and are independently operated by farmers, more localized municipalities, or local landowners. Although daily discharge data was available at the Vrchlice basin's outlet, it is not practical to calibrate and validate this SWAT model at the daily timestep due to these unknown reservoir management regimes. Additionally, there is no spatial database for crop rotations across the Czech Republic by individual farmers, so the crop rotation was estimated and randomized across the Vrchlice basin based on the major crops provided by the Czech Statistical Office [23]. Even with SWAT's modeling limitations and some data quality limitations, SWAT was still able to effectively model the water balance at the Vrchlice basin, especially in the context of scenario analysis, which can provide insight for managers concerning the localized effects of land-use and management changes across the basin. Additional data would be necessary to model other basin processes or to model Vrchlice at the sub-basin scale, such as actual crop rotation, agricultural management activities, and reservoir management.

\subsection{Small Water Cycle Response to Land-Use and Management Changes}

Other than evapotranspiration, all other water balance variables were affected by the land-use changes in the Vrchlice basin. The most stable flows in the Vrchlice basin were modeled in the 2019 land-use scenario, which may be due to an increased forest cover, reduced crop cover, redistributed brush cover, and more reservoirs across the basin, all of which can aid a landscape in retaining and reducing the impact of extreme weather events [30-37]. The systematic incorporation of subsurface tile drainage systems 
in agricultural lands seems to explain most of the patterns observed in the other water balance variables. The 1852 and 1954 land-use scenarios occur without the tile drainage systems and before the total transformation of the landscape due to the Communist Era policies; these two scenarios exhibit very similar patterns of soil water content, average subsurface lateral flow, and percent precipitation as surface runoff. In these two scenarios, surface runoff and soil water content are higher across the entire year, and subsurface lateral flow is highest from January through August. Reduced surface runoff is expected with the incorporation of a tile drainage system because the system drains soils faster than they would naturally, allowing water to infiltrate at a greater rate. Further studies would need to be conducted to isolate the effects of the tile drainage system incorporation versus the incorporation of the large, monotonous fields and reduced buffer zones during the Communist Era. The reduced subsurface lateral flow in the 1983 and 2019 land-use scenarios is unexpected and likely an artifact of the incorporation of the subsurface tile drainage systems as SWAT separates tile flow from subsurface lateral flow. However, while this tile flow is technically subsurfaced, it is transformed into streamflow much faster than a natural subsurface lateral flow, which SWAT is unable to encompass at this timestep [38]. Additionally, the presence of tile drainage systems can cause severe nutrient issues in watersheds, including increased nitrate and phosphorous in stream systems. However, such is not in the scope of this study and should be explored at the sub-basin scale in Vrchlice [39-41]. Sediment and erosion processes are also not included in the scope of this study but again should be explored at the sub-basin scale and in sub-basins with detailed reservoir and agricultural management practices with HRUs defined by the field boundary method [42,43].

When isolating the effects of crop changes across the three most recent political eras of the Czech Republic (pre-Communist, Communist, and post-Communist; Table 3), the Communist Era crop rotation reinforced the small water cycle the least, followed by the post-Communist Era, and the pre-Communist Era crop rotation reinforced the small water cycle the most. The post-Communist Era crop rotation is largely driven by winter wheat and rapeseed. Both of these crops exhibit high transpiration rates, and rapeseed is planted in an unfavorable way with seedbed conditions present during the Czech rainy season [20]; these factors lead to the reduced soil water content, increased surface runoff ratios, and the reduced subsurface lateral flow observed in the post-Communist Era. The Communist Era crop rotation reinforced the small water cycle the least, resulting in the most water being transported out of the basin as streamflow. The Communist Era crop rotation is dominated by oats, winter wheat, and spring barley. With spring barley being a major crop during this time period, its management leaves soils bare for longer, which results in an overall higher surface runoff ratio as well as a higher soil water content driven by reduced transpiration.

\section{Conclusions}

This study has shown that SWAT can be effectively used at the management scale in the Czech landscape. The effects on the small water cycle of both land-use changes and landscape management changes were easily isolated through the use of SWAT. While there have been some improvements in the functionality of the Czech agricultural landscape since the fall of communism, there are still areas that need attention from watershed managers. Increasing forested, brush, and grassland areas can contribute significantly to this goal. While sub-surface tile drainage systems superficially seem to reinforce the small water cycle, they may introduce other water quality issues in the Czech landscape that are not in the scope of this study and should be examined further.

The crop rotation that reinforces the small water cycle the most is the pre-Communist Era configuration. The current crop rotation in the Czech Republic is an improvement over the crop management during the Communist Era concerning the reinforcement of the small water cycle. However, there are still improvements that could be made across the landscape. A more diverse crop rotation should be incentivized to farmers to reinforce the small water cycle and to make the small water cycle more stable. Additionally, as hydrological 
modeling becomes more commonplace, it is increasingly necessary to foster relationships and collaboration between scientists, landowners, and watershed managers. Central databases for reservoir management and agricultural (crop and practice) management would be invaluable to researchers and basin managers to be able to aid landowners in making informed decisions.

Author Contributions: N.N. and T.D. conceived of and designed the study; J.W. and J.K. provided input data; N.N. developed, ran, calibrated and validated the SWAT model; N.N. and T.L. ran statistical analyses; N.N. wrote the manuscript; N.N. and T.L. made the figures; T.D., T.L., J.W. and J.K. edited the manuscript. All authors have read and agreed to the published version of the manuscript.

Funding: The presented research has been performed within projects H2020 No. 773903 Shui, focused on water scarcity in European and Chinese cropping systems and the Grant Agency of Czech Technical University in Prague, No. SGS20/156/OHK1/3T/11.

Institutional Review Board Statement: Not applicable.

Informed Consent Statement: Not applicable.

Conflicts of Interest: The authors declare no conflict of interest.

\section{Appendix A}

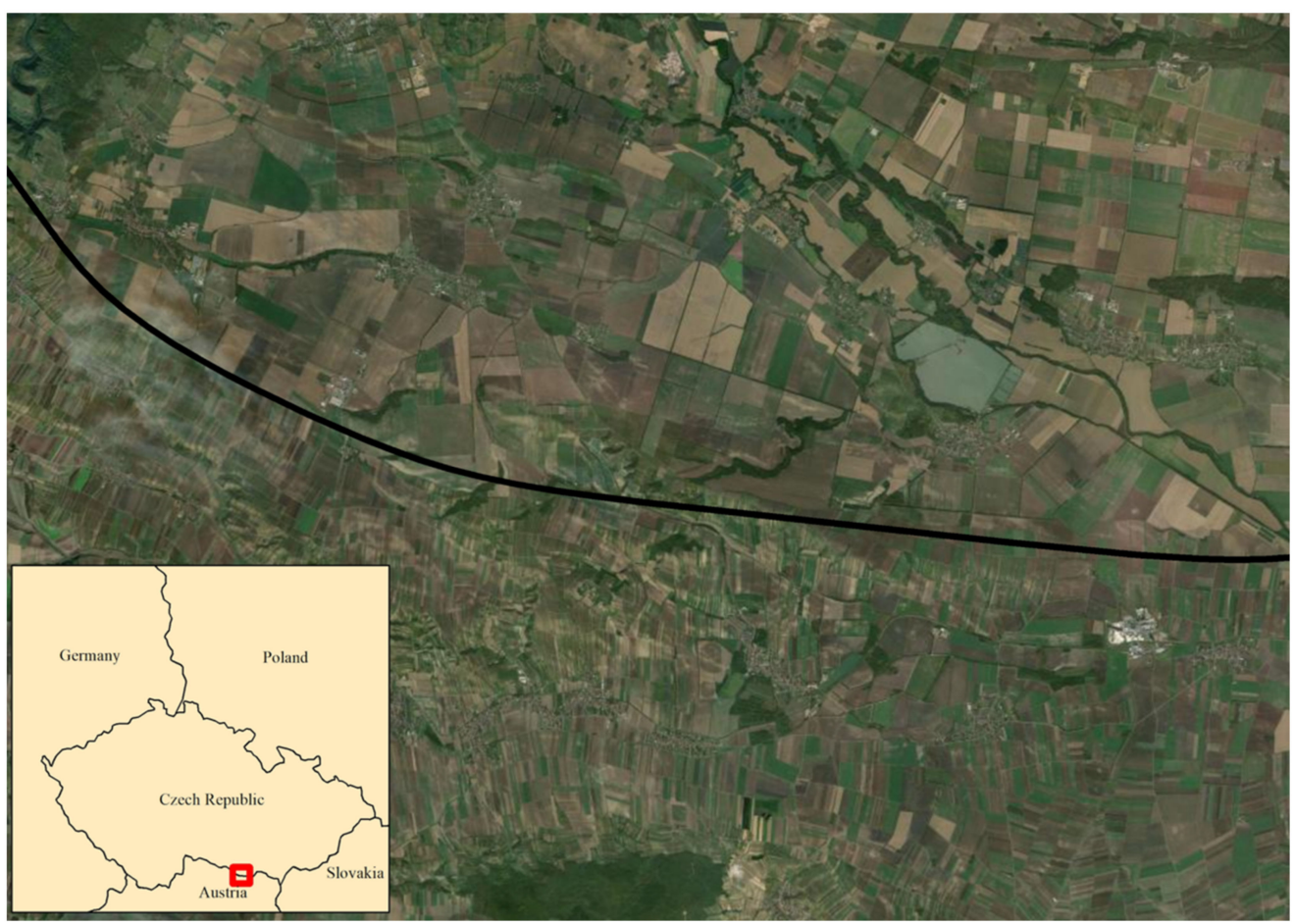

Figure A1. Field size discrepancies between the Czech Republic and Austria [7].

\section{References}

1. Ministry of Agriculture of the Czech Republic. We Support Traditions and Rural Development in the Czech Republic; Ministry of Agriculture of the Czech Republic: Prage, Czech Republic, 2018; ISBN 978-80-7434-416-9.

2. Massy, C. Transforming landscapes: Regenerating country in the Anthropocene. Griffith REVIEW 2019, 63, 247-261. [CrossRef]

3. Marlow, D. Small water cycles: What they are, their importance, their restoration. In Proceedings of the Royal Society of Queensland, 2020. Available online: http://www.royalsocietyqld.org/wp-content/uploads/documents/Stewardship/Rangelands\% 20Policy\%20Dialogue/Rangelands\%20Briefs/Marlow-small-water-cycles.pdf (accessed on 1 September 2021).

4. Kravčík, M.; Lambert, J. A Global Action Plan for the Restoration of Natural Water Cycles and Climate. Available online: http:/ /ircsa.ir/files/site1/files/149_kravcik_global_action_plan.pdf (accessed on 1 September 2021).

5. Kravčík, M.; Pokorný, J.; Kohutiar, J.; Kováč, M.; Tóth, E. (Eds.) Water for the recovery of the climate-A new water paradigm. In Proceedings of the APLU and ICA, Prague, Czech Republic, 23-26 June 2009. 
6. Zeleňáková, M.; Fialová, J.; Negm, A.M. Assessment and Protection of Water Resources in the Czech Republic; Springer: Cham, Switzerland, 2020; ISBN 9783030183639.

7. Esri. World Map with Imagery; Esri: Redlands, CA, USA, 2021.

8. Krasa, J.; Dostal, T.; Van Rompaey, A.; Vaska, J.; Vrana, K. Reservoirs' siltation measurments and sediment transport assessment in the Czech Republic, the Vrchlice catchment study. CATENA 2005, 64, 348-362. [CrossRef]

9. Fiener, P.; Dostál, T.; Krása, J.; Schmaltz, E.; Strauss, P.; Wilken, F. Operational USLE-Based Modelling of Soil Erosion in Czech Republic, Austria, and Bavaria-Differences in Model Adaptation, Parametrization, and Data Availability. Appl. Sci. 2020, 10, 3647. [CrossRef]

10. Tlapáková, L. Development of drainage system in the Czech landscape-Identification and functionality assessment by means of remote sensing. Eur. Countrys. 2017, 9, 77-98. [CrossRef]

11. Stych, P.; Kabrda, J.; Bicik, I.; Lastovicka, J. Regional Differentiation of Long-Term Land Use Changes: A Case Study of Czechia. Land 2019, 8, 165. [CrossRef]

12. European Commission. Directive 2009/28/EC of the European Parliament and of the Council of 23 April 2009: On the Promotion of the Use of Energy from Renewable Sources and Amending and Subsequently Repealing Directives 2001/77/EC and 2003/30/EC; European Commission: Brussels, Belgium, 2009.

13. Arnold, J.G.; Srinivasan, R.; Muttiah, R.S.; Williams, J.R. Large Area Hydrologic Modeling and Assessment Part I: Model Development. JAWRA J. Am. Water Resour. Assoc. 1998, 34, 73-89. [CrossRef]

14. Neitsch, S.L.; Arnold, J.G.; Kiniry, J.R.; Williams, J.R. Soil and Water Assessment Tool Theoretical Documentation; Texas Water Resources Institute: College Station, TX, USA, 2011.

15. Gassman, P.W.; Reyes, M.R.; Green, C.H.; Arnold, J.G. The Soil and Water Assessment Tool: Historical Development, Applications, and Future Research Directions. Trans. ASABE 2007, 50, 1211-1250. [CrossRef]

16. Melaku, N.D.; Renschler, C.S.; Holzmann, H.; Strohmeier, S.; Bayu, W.; Zucca, C.; Ziadat, F.; Klik, A. Prediction of soil and water conservation structure impacts on runoff and erosion processes using SWAT model in the northern Ethiopian highlands. J. Soils Sediments 2018, 18, 1743-1755. [CrossRef]

17. Ondr, P.; Pečenka, J.; Polenský, J.; Ciml, J. Effect of land use changes on water run-off from a small catchment in the Czech Republic. Ekológia (Bratislava) 2016, 35, 78-89. [CrossRef]

18. Du, B.; Ji, X.; Harmel, R.D.; Hauck, L.M. Evaluation of a Watershed Model for Estimating Daily Flow Using Limited Flow Measurements. JAWRA J. Am. Water Resour. Assoc. 2009, 45, 475-484. [CrossRef]

19. Brzozowski, J.; Miatkowski, Z.; Śliwiński, D.; Smarzyńska, K.; Śmietanka, M. Application of SWAT model to small agricultural catchment in Poland. J. Water Land Dev. 2011, 15, 157-166. [CrossRef]

20. Noreika, N.; Li, T.; Zumr, D.; Krasa, J.; Dostal, T.; Srinivasan, R. Farm-Scale Biofuel Crop Adoption and Its Effects on In-Basin Water Balance. Sustainability 2020, 12, 10596. [CrossRef]

21. Gregar, J.; Petrů, J.; Novotná, J. Evaluation of the SWAT model as an integrated management tool in the Švihov drinking water supply catchment. Soil Water Res. 2019, 14, 76-83. [CrossRef]

22. Winterova, J. Sediment Transport in Vrchlice Reservoir Watershed. Master's Thesis, Czech Technical University in Prague, Prague, Czech Republic, 2020. (In Czech).

23. Czech Statistical Office. Harvest Estimates. 2021. Available online: https://www.czso.cz/csu/czso/ari/harvest-estimatesseptember-2020 (accessed on 1 September 2021).

24. Moriasi, D.N.; Arnold, J.G.; Van Liew, M.W.; Bingner, R.L.; Harmel, R.D.; Veith, T.L. Model Evaluation Guidelines for Systematic Quantification of Accuracy in Watershed Simulations. Trans. ASABE 2007, 50, 885-900. [CrossRef]

25. Tuppad, P.; Douglas-Mankin, K.R.; Lee, T.; Srinivasan, R.; Arnold, J.G. Soil and Water Assessment Tool (SWAT) Hydrologic/Water Quality Model: Extended Capability and Wider Adoption. Trans. ASABE 2011, 54, 1677-1684. [CrossRef]

26. Nyeko, M. Hydrologic Modelling of Data Scarce Basin with SWAT Model: Capabilities and Limitations. Water Resour. Manag. 2015, 29, 81-94. [CrossRef]

27. Beven, K. How far can we go in distributed hydrological modelling? Hydrol. Earth Syst. Sci. 2001, 5, 1-12. [CrossRef]

28. Martínez-Retureta, R.; Aguayo, M.; Stehr, A.; Sauvage, S.; Echeverría, C.; Sánchez-Pérez, J.-M. Effect of Land Use/Cover Change on the Hydrological Response of a Southern Center Basin of Chile. Water 2020, 12, 302. [CrossRef]

29. Zumr, D.; Jeřábek, J.; Klípa, V.; Dohnal, M.; Sněhota, M. Estimates of Tillage and Rainfall Effects on Unsaturated Hydraulic Conductivity in a Small Central European Agricultural Catchment. Water 2019, 11, 740. [CrossRef]

30. Zhang, M.; Liu, N.; Harper, R.; Li, Q.; Liu, K.; Wei, X.; Ning, D.; Hou, Y.; Liu, S. A global review on hydrological responses to forest change across multiple spatial scales: Importance of scale, climate, forest type and hydrological regime. J. Hydrol. 2016, 546, 44-59. [CrossRef]

31. David, T.; Henriques, M.; Tomé, J.; Ledger, D. Clearcutting effects on streamflow in coppiced Eucalyptus globulus stands in Portugal. J. Hydrol. 1994, 162, 143-154. [CrossRef]

32. Stednick, J.D. Monitoring the effects of timber harvest on annual water yield. J. Hydrol. 1996, 176, 79-95. [CrossRef]

33. Neary, D.G.; Gottfried, G.J.; Folliott, P.F. (Eds.) Post-wildfire watershed flood responses. In Proceedings of the 2nd International Fire Ecology Conference, Orlando, FL, USA, 16-20 November 2003.

34. Beck, H.E.; Bruijnzeel, L.A.; van Dijk, A.I.J.M.; McVicar, T.R.; Scatena, F.N.; Schellekens, J. The impact of forest regeneration on streamflow in 12 mesoscale humid tropical catchments. Hydrol. Earth Syst. Sci. 2013, 17, 2613-2635. [CrossRef] 
35. Wu, W.; Hall, C.A.S.; Scatena, F.N. Modelling the impact of recent land-cover changes on the stream flows in northeastern Puerto Rico. Hydrol. Process. 2007, 21, 2944-2956. [CrossRef]

36. Webb, A.A.; Kathuria, A. Response of streamflow to afforestation and thinning at Red Hill, Murray Darling Basin, Australia. J. Hydrol. 2011, 412-413, 133-140. [CrossRef]

37. Bruijnzeel, L. Hydrological functions of tropical forests: Not seeing the soil for the trees? Agric. Ecosyst. Environ. 2004, 104, 185-228. [CrossRef]

38. Moriasi, D.N.; Rossi, C.G.; Arnold, J.G.; Tomer, M.D.; Tufekcioglu, M.; Isenhart, T.; Schultz, R.; Bear, D.; Kovar, J.; Russell, J. Evaluating hydrology of the Soil and Water Assessment Tool (SWAT) with new tile drain equations. J. Soil Water Conserv. 2012, 67, 513-524. [CrossRef]

39. Smith, D.R.; King, K.W.; Johnson, L.; Francesconi, W.; Richards, P.; Baker, D.; Sharpley, A.N. Surface Runoff and Tile Drainage Transport of Phosphorus in the Midwestern United States. J. Environ. Qual. 2015, 44, 495-502. [CrossRef] [PubMed]

40. Randall, G.W.; Goss, M.J. Nitrate Losses to Surface Water Through Subsurface, Tile Drainage. In Nitrogen in the Environment: Sources, Problems, and Management, 2nd ed.; Hatfield, J.L., Follett, R.F., Eds.; Academic Press: London, UK, 2008 ; pp. 145-175. ISBN 9780123743473.

41. Amado, A.A.; Schilling, K.E.; Jones, C.S.; Thomas, N.; Weber, L.J. Estimation of tile drainage contribution to streamflow and nutrient loads at the watershed scale based on continuously monitored data. Environ. Monit. Assess. 2017, 189, 426. [CrossRef]

42. Pai, N.; Saraswat, D.; Srinivasan, R. Field_SWAT: A tool for mapping SWAT output to field boundaries. Comput. Geosci. 2012, 40, 175-184. [CrossRef]

43. Daggupati, P.; Douglas-Mankin, K.R.; Sheshukov, A.Y.; Barnes, P.L.; Devlin, D.L. Field-Level Targeting Using SWAT: Mapping Output from HRUs to Fields and Assessing Limitations of GIS Input Data. Trans. ASABE 2011, 54, 501-514. [CrossRef] 